\title{
PENINGKATAN AKTIVITAS DAN HASIL BELAJAR KONSEP REDOKS DAN ELEKTROLISIS DENGAN MODEL DISCOVERY LEARNING PADA SISWA KELAS XII MIPA 1 SMAN 12 BANJARMASIN
}

\author{
Saidah \\ Sekolah Menengah Atas Negeri 12 Banjarmasin \\ E-mail : saidah356@gmail.com
}

Website : https://jurnal.uin-antasari.ac.id/index.php/ptkpend/index

Received: November 2018; Accepted: April 2019; Published: Agustus 2019

\begin{abstract}
This study aims to find out the discovery learning model on chemistry subjects through laboratory activities on the Redox and Electrolysis concepts can increase student activities and learning outcomes in class XII MIPA 1 at SMAN 12 Banjarmasin academic year 2017/2018. The method used is Classroom Action Research with 35 students. The research instruments used was the learning outcome test and student activities sheet. The results of the research in the first cycle were the most good activities, namely 23 students (60.53\%), while the activities of students were enough as many as 15 students (39.47\%) while in the second cycle the activities of the students were the most excellent at 30 students $(78.95 \%)$, while good student activities are 8 students $(21.05 \%)$. Student learning outcomes in the first cycle of students who completed as many as 17 students $(44.74 \%)$ while the incomplete as many as 21 students $(55.26 \%)$. The complete second cycle of students was 34 students $(89.47 \%)$ while the incomplete students were 4 students $(10.53 \%)$. Changes in completeness of students in cycle I to II with a level of $44.73 \%$
\end{abstract}

Keywords: activities; learning outcomes; discovery learning

\begin{abstract}
ABSTRAK
Penelitian ini bertujuan mengetahui model pembelajaran Discovery Learning pada mata pelajaran Kimia melalui kegiatan laboratorium pada Konsep Redoks dan Elektrolisis dapat meningkatkan aktivitas siswa dan hasil belajar kelas XII MIPA 1 pada SMAN 12 Banjarmasin tahun pelajaran 2017/2018. Metode yang digunakan adalah Peneltian Tindakan Kelas dengan jumlah siswa 35 orang. Instrumen penelitian yang digunakan adalah tes hasil belajar dan lembar aktivitas siswa. Hasil Penelitian pada siklus I yang paling banyak adalah beraktivitas baik yakni 23 siswa $(60,53 \%)$, sedangkan aktivitas siswa cukup sebanyak 15 siswa $(39,47 \%)$ sedangkan pada siklus II aktivitas siswa yang paling banyak adalah berkativitas baik sekali yakni 30 siswa $(78,95 \%)$, sedangkan aktivitas siswa baik sebanyak 8 siswa $(21,05 \%)$. Hasil belajar siswa Siklus I siswa yang tuntas sebanyak 17 siswa $(44,74 \%)$ sedangkan yang tidak tuntas sebanyak 21 siswa $(55,26 \%)$. Siklus II siswa yang tuntas sebanyak 34 siswa $(89,47 \%)$ sedangkan yang tidak tuntas sebanyak 4 siswa $(10,53 \%)$. Perubahan ketuntasan siswa pada siklus I ke II dengan tingkatan sebesar $44,73 \%$.
\end{abstract}

Kata Kunci: aktivitas; hasil belajar; discovery learning

\section{PENDAHULUAN}

Pendidikan merupakan aspek yang paling penting dalam menunjang kemajuan bangsa di masa depan, karena melalui pendidikan manusia dapat mengembangkan potensi-potensi yang ada dalam dirinya baik itu potensi rohani (pikir, rasa dan budi pekerti) maupun jasmani (panca indera serta keterampilan). Kesadaran terhadap pentingnya pendidikan mendorong manusia untuk ikut serta secara aktif dalam kegiatan pendidikan. Karena pendidikan merupakan sarana untuk 
mencerdaskan kehidupan bangsa dan mencapai kesejahteraan lahir dan batin.

Menurut Abuddin Nata (2009) Kemajuan suatu bangsa mengharuskan adanya sumber daya manusia yang unggul, dan adanya manusia yang unggul mengharuskan adanya pendidikan yang unggul, dan adanya pendidikan yang unggul mengharuskan adanya berbagai komponen atau aspek pendidikan yang unggul pula. Kepada pendidikan yang unggul itulah harapan untuk membangun bangsa yang unggul akan dapat diwujudkan. Oleh karena itu, kesadaran dan keinginan yang kuat dari pemerintah dan rakyat Indonesia perlu dilakukan untuk memperbaiki mutu pendidikan di Indonesia. Salah satunya melalui lembaga pendidikan yaitu sekolah harus memenuhi kebutuhan tersebut dengan memperhatikan proses pembelajaran yang diterapkan.

Penting sekali bagi guru untuk memahami sebaik-baiknya proses belajar siswa, agar ia dapat memberikan bimbingan dan menyediakan lingkungan belajar yang tepat dan serasi bagi siswa, Oemar Hamalik (2002).

Pengalaman imperis peneliti sebagai pengajar kelas XII MIPA 1 pada SMAN 12 Banjarmasin, walaupun mereka program studi IPA minat siswa terhadap pelajaran kimia, bahwa kimia merupakan pelajaran yang sulit, karena siswa hanya mengandalkan hafalan rumus dan konsep saja. Aktifitas siswa agak terbatas pada mengingat informasi, mengungkapkan kembali apa yang telah dikuasainya, dan bertanya kepada guru tentang bahan yang belum dipahaminya. Hasil belajar kimia secara klasikal masih di bawah $80 \%$ secara kalsikal tuntas.

Hal tersebut sesuai dengan pendapat Rogers yang mengatakan bahwa praktek pendidikan lebih di titik beratkan pada segi pengajaran bukan pada siswa yang belajar. Praktek tersebut ditandai oleh peran guru yang dominan dan siswa hanya menghafalkan pelajaran (Putrayasa, 2013). Dominasi guru dalam proses pembelajaran menyebabkan siswa lebih banyak terlibat pasif. Para siswa lebih banyak menerima transfer ilmu dari guru daripada mencari dan menemukan sendiri pengetahuan, keterampilan, dan sikap yang mereka butuhkan. Selain itu, peneliti juga menemukan bahwa laboratorium kurang difungsikan untuk kegiatan pembelajaran karena kegiatan pemebelajaran hanya terbatas pada mencatat, latihan dan hafalan saja. Pelajaran hanya terfokus di kelas yang kurang menarik perhatian siswa dan cenderung membosankan sehingga membuat siswa sulit untuk mempelajari kimia karena hanya mengandalkan hafalan.

Pembelajaran konvensional kurang memberikan kesempatan bagi siswa untuk membangun sendiri struktur kognitifnya, serta kesempatan untuk menumbuh kembangkan minat dan sikap ilmiahnya, Hamdani. (2011). Hal ini membuat siswa tidak cukup untuk memperoleh pengetahuan yang dalam.

Dalam mempelajari kimia, siswa memerlukan pengetahuan yang mendalam untuk memahami konsepkonsep yang ada di dalam pelajaran kimia. Ilmu kimia merupakan pelajaran yang kompleks, dimana siswa tidak hanya dituntut untuk memiliki kemampuan dalam berhitung tetapi juga dituntut untuk menguasai konsep. Penguasaan konsep-konsep kimia serta saling keterkaitannya mempunyai model yang berbeda satu dengan yang lainnya sesuai dengan materi yang dipelajari dan tujuan yang hendak dicapai. Salah satu konsep yang dipelajari pada mata pelajaran kimia di kelas XII adalah Konsep Redoks dan Elektrolisis. Dalam mempelajari Konsep Redoks dan Elektrolisis memerlukan kegiatan yang dapat membangun pengetahuan siswa bukan hanya sekedar hafalan semata. Siswa harus secara pribadi melakukan berbagai kegiatan yang melibatkan proses mentalnya seperti mengadakan pengamatan di laboratorium, melakukan 
percobaan, bersimulasi, mengadakan penelitian sederhana, dan memecahkan masalah, Ibrahim dan Nana Syaodih (2003). Untuk itu perlu diterapkan model pembelajaran yang jitu dalam menggiring siswa agar lebih menyenangi belajar kimia dan dapat mencapai ketuntasan belajar memahami konsep yang dipelajari seperti konsep Redoks dan Elektrolisis. Peneliti mencoba menerapkan salah satu model pembelajaran yakni Discovery Learning.

Pembelajaran dengan model discovery melatih siswa untuk mendapatkan jawaban-jawabannya sendiri berdasarkan temuannya atau menemukan lagi sesuatu yang ditemukan (membuktikan kembali). Itu berarti, melalui model discovery akan memberikan kesempatan kepada siswa untuk mengembangkan ide dan gagasannya dalam usahanya untuk memecahkan masalah. Pembelajaran dengan model discovery juga dapat lebih memberikan pemahaman kepada siswa dan lebih mudah diingat serta lebih lama melekat.

Pembelajaran dengan model discovery dapat merubah cara pandang siswa tentang pelajaran sains dalam hal ini pelajaran kimia yang oleh sebagian besar siswa dianggap cukup sukar untuk memahaminya jika dipelajari hanya melalui teori. Dalam pelajaran kimia dibutuhkan cara berpikir, pemahaman pelajaran yang berbeda dan pengalaman langsung. Karena model discovery dapat merubah konsep pembelajaran kimia tidak hanya menjadi pelajaran penghapalan konsep-konsep saja. Dengan demikian untuk menumbuhkembangkan cara berpikir, pemahaman, cara untuk menyelidiki dan keingintahuan siswa, perlu diterapkan cara belajar di sekolah dengan model discovery, karena dengan begitu siswa akan lebih menyenangi pelajaran kimia.

Pelajaran kimia di sekolah harus dibuat menarik, terutama dari segi penyampaian dan media yang digunakan.
Cara penyampaian yang mengundang rasa ingin tahu kepada siswa akan memberi sumbangan besar untuk membuat pelajaran kimia menjadi menarik, bukan sebaliknya. Hal tersebut dapat dilakukan dengan kegiatan laboratorium/praktikum. Dengan melakukan kegiatan praktikum, siswa tidak hanya dijejali rumus-rumus saja yang kelihatannya rumit dan membosankan tapi siswa juga diberikan kegiatan yang membuat siswa menjadi tahu bagaimana proses kimia berlangsung.

Dalam model discovery melalui kegiatan laboratorium banyak keterampilan proses yang dapat dikembangkan, siswa diikutsertakan dalam proses penyelidikan dan melalui keterlibatan siswa itu akan memperoleh pemahaman konsep yang benar, terampil, dan mampu membuat kesimpulan. Kegiatan penyelidikan memberikan pengalaman konkret sehingga siswa mengingat ide-ide abstrak tanpa harus mengahafalkannya, seperti dalam mempelajari konsep Redoks dan Elektrolisis, dengan standar kompetensi Menerapkan konsep reaksi oksidasireduksi dan ektrokimia dalam teknologi dan kehidupan sehari-hari.

Model discovery yang menitikberatkan pada pengalaman langsung melalui kegiatan laboratorium, maka siswa dapat langsung melihat, mendengar, meraba, serta melakukan percobaaan sendiri. Dengan cara demikian hasil belajar akan bersifat permanen atau tidak mudah dilupakan.

Berdasarkan latar belakang tersebut maka perlu dilakukan penelitian dengan tujuan untuk mengetahui model pembelajaran Discovery Learning pada mata pelajaran Kimia melalui kegiatan laboratorium pada Konsep Redoks dan Elektrolisis dapat meningkatkan aktivitas siswa dan hasil belajar kelas XII MIPA 1 pada SMAN 12 Banjarmasin tahun pelajaran 2017/2018. 


\section{METODE PENELITIAN}

Jenis penelitian yang digunakan adalah Penelitian Tindakan Kelas (PTK). Penelitian ini menggunakan model Kemmis dan Mc. Taggart (dalam Wijaya Kusuma dan Dedi Dwitagama, 2011: 19-24). Pelaksanaan penelitian tindakan meliputi empat langkah yaitu perencanaan (planning), tindakan (action), pengamatan (observation), dan refleksi (reflection).

Penelitian ini dilaksanakan di kelas XII MIPA 1 pada SMAN 12 Banjarmasin pada bulan Januari-April 2018 dengan menyesuaikan jadwal peneliti mengajar. Subjek penelitian adalah siswa kelas XII MIPA 1 sebanyak 35 siswa terdiri dari 16 Laki-laki 19 Perempuan pada SMAN 12 Banjarmasin semester Genap tahun pelajaran 2017/2018.

Analisis data dalam penelitian tindakan kelas ini dilakukan melalui tiga tahap. Tahap pertama adalah mereduksi data, yaitu menyeleksi data sesuai dengan fokus masalah. Pada tahapan ini peneliti mengumpulkan semua instrumen yang digunakan untuk mengumpulkan data kemudian dikelompokan berdasarkan fokus masalah. Tahap kedua, mendiskripsikan data sehingga data telah dikumpulkan menjadi bermakna. Mendiskripsikan data bisa dilakukan dalam bentuk naratif, membuat grafik dan menyusunnya dalam bentuk table atau diagram. Tahap yang ketiga, adalah membuat kesimpulan berdasarkan deskripsi data (Wina, 2009: 106-107).

a. Hasil Belajar

Nilai hasil belajar

$$
\mathrm{N}=\frac{\mathrm{P}}{\mathrm{Q}}
$$

Keterangan :

$$
\begin{aligned}
& \mathrm{N}=\text { Nilai Hasil Belajar } \\
& \mathrm{P}=\text { Skor yang diperoleh } \\
& \mathrm{Q}=\text { Skor Maksimal }
\end{aligned}
$$

b. Ketuntasan

Untuk menghitung ketuntasan belajar siswa dengan rumus :

$$
\mathrm{KB}=\frac{\mathrm{N}}{\mathrm{n}} \times 100 \%
$$
Keterangan:
$\mathrm{KB}=$ Ketuntasan Belajar
$\mathrm{N}=\underset{75}{\mathrm{Jumlah}}$ siswa yang mendapat nilai $\geq$
$\mathrm{n}=$ Jumlah seluruh siswa

(Trianto, 2010:241)

c. Lembar observasi aktivitas Siswa

Data jumlah siswa yang terlibat dalam masing-masing aktivitas dan dipersentasikan dengan rumus.

Dimana $P=\frac{F}{N} \times 100 \%$

$\mathrm{P}=$ Angka persentase aktivitas

$\mathrm{F}=$ Jumlah skor Aspek yang diperoleh

$\mathrm{N}=$ Jumlah Maksimal Aspek

Interpretasi aktivitas belajar dilakukan sebagaimana yang dikemukakan

Arikunto (2008 : 251) sebagai berikut :

Tabel 1. Kategori Aktivitas Siswa

\begin{tabular}{ll}
\hline \multicolumn{1}{c}{ Persentase aktivitas } & \multicolumn{1}{c}{ Kategori } \\
\hline $25 \%<\mathrm{P}<40 \%$ & Kurang Sekali \\
\hline $40 \%<\mathrm{P}<54 \%$ & Kurang \\
\hline $55 \%<\mathrm{P}<69 \%$ & Cukup \\
\hline $70 \%<\mathrm{P}<85 \%$ & Baik \\
\hline $86 \%<\mathrm{P}<100 \%$ & Baik Sekali \\
\hline
\end{tabular}

Indikator kinerja dalam penelitian ini adalah penggunaan pembelajaran model discovery learning kemampuan hasil belajar dan aktivitas siswa dalam pembelajaran Kimia dengan materi dalam memahami Konsep Redoks dan Elektrolisis dengan metode discovery learning.

\section{HASIL PENELITIAN}

\section{Deskripsi Pelaksanaan Penelitian Tindakan Kelas}

Penelitian ini direncanakan dua siklus, diawali dengan pra tindakan dengan tujuan untuk mengetahui sejauh mana aktivitas dan hasil belajar siswa dalam pembelajaran Matematika di kelas XII MIPA 1 pada SMAN 12 Banjarmasin, selanjutnya peneliti melakukan Penelitian Tindakan kelas (Action Research) dengan menerapkan siklus I dan Siklus II. 


\section{Pra Tindakan}

Dalam pelaksanaan pra tindakan peneliti mengamati aktivitas siswa dalam pembelajaran, banyak siswa dengan aktivitas beragam dengan kata lain siswa ada yang menggangu teman pada saat kerja kelompok, ada yang terpusat mengerjakan tugas hanya pada satu orang dalam kelompoknya dan hasil belajar hampir $65 \%$ di bawah KKM.

\section{Siklus I}

\section{a. Penilaian Hasil Belajar Siswa}

Data hasil tes pada siklus I diperoleh berdasarkan tes tertulis siswa yang berbentuk soal uraian berjumlah 10 soal. Soal tes dan hasil tes siklus I. Berikut hasil nilai pretes dan postes siklus I siswa.

\section{Tabel 2 Hasil Pretes dan Postes Siklus I}

\begin{tabular}{|c|c|c|}
\hline Kriteria & $f$ & $\%$ \\
\hline \multicolumn{3}{|l|}{ Pre test } \\
\hline - Tuntas & 11 & 31,42 \\
\hline - $\quad$ Tidak Tuntas & 24 & 68,58 \\
\hline Total & 35 & 100 \\
\hline \multicolumn{3}{|l|}{ Post Test } \\
\hline - Tuntas & 24 & 68,58 \\
\hline - $\quad$ Tidak Tuntas & 11 & 31,42 \\
\hline Total & 35 & 100 \\
\hline \multicolumn{3}{|l|}{ Pre Test } \\
\hline - Rata-rata & \multicolumn{2}{|c|}{66,29} \\
\hline - Nilai Max & \multicolumn{2}{|c|}{90} \\
\hline - Nilai Min & \multicolumn{2}{|c|}{40} \\
\hline \multicolumn{3}{|l|}{ Pre Test } \\
\hline - Rata-rata & \multicolumn{2}{|c|}{73,43} \\
\hline - Nilai Max & \multicolumn{2}{|c|}{90} \\
\hline - Nilai Min & \multicolumn{2}{|c|}{50} \\
\hline
\end{tabular}

Nilai rata-rata pretes sebesar 66,29 , nilai tertinggi yang diperoleh siswa sebesar 90, dan untuk nilai terendah sebesar 40. Sedangkan pada nilai rata-rata postes sebesar 69,71, nilai tertinggi yang diperoleh siswa sebesar 90, dan untuk terendah sebesar 30.

Kriteria Ketuntasan pada pre test yang tuntas 11 siswa $(31,42 \%)$ dan yang tidak tuntas 24 siswa $(68,58 \%)$, sedangkan pada saat post tes tuntas 24 siswa $(68,58 \%)$ dan tidak tuntas 11 siswa $(31,42 \%)$.

\section{b. Hasil penilaian Aktivitas siswa siklus I}

Berdasarkan perhitungan penilaian aspek afektif siswa pada pertemuan ke-I diperoleh persentase pencapaian seperti pada table di bawah ini:

Tabel 3. Kategori Afektif Siswa Siklus I

\begin{tabular}{lcc}
\hline \multicolumn{1}{c}{ Kategori } & f & $\%$ \\
\hline Cukup & 25 & 71,43 \\
\hline Baik & 10 & 28,57 \\
\hline
\end{tabular}

Aktivitas siswa berkategori cukup sebanyak 25 siswa dengan presentase sebesar $71,43 \%$. Sedangkan yang berkategori baik sebanyak 10 siswa $(28,57 \%)$

\section{c. Observasi}

Dalam tahap observasi peneliti dibantu oleh kolaborator untuk menilai para siswa dalam pembelajaran. Sasaran observasi pada pertemuan difokuskan pada keseluruhan aktivitas siswa pada proses pembelajaran, kesulitan yang mereka hadapi, maupun sikap yang mereka lakukan. Selama proses pembelajaran pada siklus I, pertemuan I, II dan III, ada beberapa hal yang menjadi catatan peneliti yaitu sebagai berikut:

1) Suasana diskusi dalam kelas masih ramai. Sebagian siswa ikut berpartisipasi dalam diskusi, tetapi ada pula siswa yang tidak ikut berpartisipasi.

2) Saat diskusi berlangsung, peneliti dan kolaborator berkeliling mengontrol jalannya diskusi kelompok dan sesekali siswa bertanya kepada peneliti dan teman jika mereka menemui kesulitan dalam mengerjakan tugas yang diberikan.

3) Dalam mempresentasikan hasil diskusi mereka, siswa membacakan dan menuliskan hasil temuan mereka di papan tulis. Siswa diminta untuk memberikan pendapat atau tanggapan jika hasil kelompoknya berbeda dengan kelompok yang presentasi. Di akhir pembelajaran, peneliti dan siswa menyimpulkan tentang materi yang telah dipelajari.

\section{d. Refleksi}

$$
\text { Refleksi terhadap proses }
$$


pembelajaran dilakukan peneliti bersama kolaborator. Dari hasil diskusi dengan kolaborator, ditemukan hambatan dalam proses pembelajaran, yaitu sebagai berikut:

a. Pada pertemuan I, siswa cenderung hanya mengerjakan tugas yang diberikan dan tidak membuat catatan pada buku tulis mereka.

b. Masih ada beberapa siswa yang tidak ikut terlibat dalam mengerjakan tugas yang diberikan.

c. Saat salah satu kelompok mempresentasikan hasil temuan kelompoknya, beberapa siswa masih ramai dan bercanda dengan teman lain.

d. Pada saat tes siklus I berlangsung, beberapa siswa menanyakan jawaban dan mencocokkan hasil jawaban kepada siswa lain. Beberapa siswa terlihat berbisik-bisik dengan temannya

\section{Siklus II}

\section{a. Penilaian Hasil Belajar Siswa}

Data hasil tes pada siklus II diperoleh berdasarkan tes tertulis siswa yang berbentuk soal uraian berjumlah 10 soal. Berikut hasil nilai pretes dan postes siklus II siswa.

Tabel 4. Hasil Pretes dan Postes siklus II

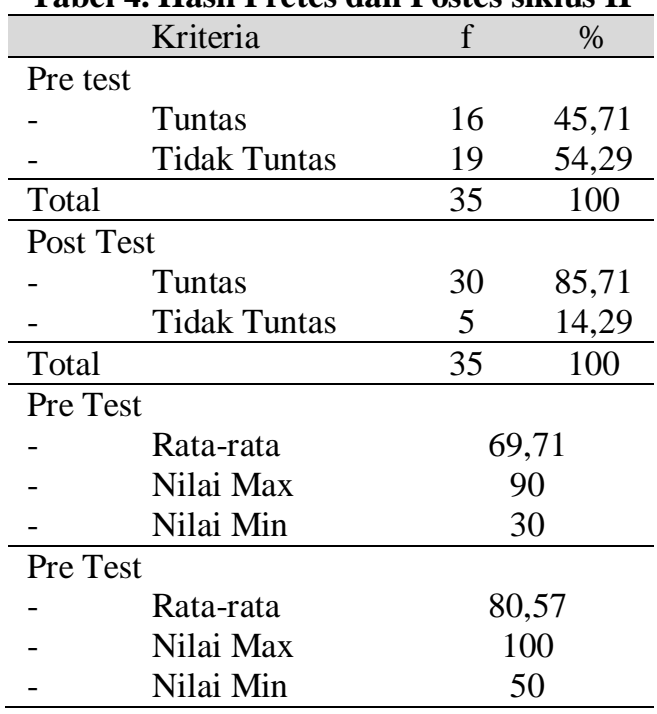

Nilai rata-rata pretes sebesar 69,71, nilai tertinggi yang diperoleh siswa sebesar 90, dan untuk nilai terendah sebesar 30 . Sedangkan pada nilai rata-rata postes sebesar 80,57, nilai tertinggi yang diperoleh siswa sebesar 100, dan untuk terendah sebesar 50.

Kriteria Ketuntasan pada pre test yang tuntas 16 siswa $(45,71 \%)$ dan yang tidak tuntas 19 siswa $(54,29 \%)$, sedangkan pada saat post tes tuntas 30 siswa $(85,71 \%)$ dan tidak tuntas 5 siswa $(14,29 \%)$.

\section{b. Hasil Penilaian Aktivitas Siswa Siklus II}

Hasil perhitungan penilaian afektif siswa siklus ke-II tergambar pada table di bawah ini

Tabel 5. Kategori Afektif Siswa Siklus II

\begin{tabular}{lcc}
\multicolumn{1}{c}{ Kategori } & $\mathrm{f}$ & $\%$ \\
\hline Cukup & 0 & 0 \\
\hline Baik & 35 & 100 \\
\hline
\end{tabular}

Presentase pencapaian kategori baik semua siswa mencapai nya yakni sebanyak 35 siswa $(100 \%)$.

\section{c. Observasi}

Secara umum, proses pembelajaran pada siklus II ini menunjukkan adanya peningkatan bila dibandingkan dengan siklus I. Hal ini ditandai dengan adanya peningkatan pada nilai afektif dan kognitif siswa. Hampir semua siswa terlibat secara aktif dalam proses pembelajaran.

\section{d. Refkleksi}

Refleksi terhadap hasil belajar siswa siklus II ini dilaksanakan melalui evaluasi dalam bentuk soal tes. Refleksi terhadap proses pembelajaran dilakukan melalui diskusi bersama-sama kolaborator.

\section{PEMBAHASAN}

1. Peningkatan Hasil Belajar Siswa dengan Discovery Learning pada Konsep Redoks dan Elektrolisis

Perbandingan nilai kognitif yang cukup signifikan. Nilai rata-rata kelas mengalami peningkatan dari 76,43 menjadi 80,57 pada postes siklus II. Sedangkan presentase ketuntasan secara klasikal naik sebesar $67,24 \%$ pada siiklus I menjadi $85,71 \%$ pada siklus II.

Berdasarkan pada tabel di atas perubahan terjadi kognitif siswa baik itu 
dari nilai rata-rata pada siklus I ke siklus II maupun pada tingkat ketuntasan secara klasikal. Oleh karena itu pembelajaran dengan menggunakan model discovery learning pada mata pelajaran Kimia Melalui Kegiatan Laboratorium Pada Konsep Redoks Dan Ekektrolisis terjadi peningkatan secara signifikan.

Sesuai apa yang dilakukan Sukmadinata, Nana Syaodih. (2003) dalam penelitiannya menyatakan bahwa yang dimaksudkan dengan proses mental tersebut adalah mengamati, mencerna, mengerti, menggolong-golongkan, membuat dugaan, menjelaskan, mengukur, dan membuat kesimpulan. Dengan kata lain, pembelajaran kimia dengan metode discovery adalah pengajaran kimia yang dirancang sedemikian rupa dari pengetahuan awal siswa sebelum ia melibatkan proses mentalnya sehingga siswa dapat menemukan konsep-konsep maupun prinsip-prinsip melalui proses mentalnya sendiri.

Hal ini dikuatkan oleh Herdian Tiga ciri utama dari belajar menemukan (discovery learning) yaitu: 1) mengeksplorasi dan memecahkan masalah untuk menciptakan, menggabungkan dan menggeneralisasi pengetahuan; 2) berpusat pada siswa; 3) kegiatan untuk menggabungkan pengetahuan baru dan pengetahuan yang sudah ada. Dari ketiga ciri yang telah disebutkan dapat dikatakan bahwa pada metode discovery, situasi belajar mengajar berpindah dari situasi teacher dominated learning menjadi situasi student dominated learning yang melibatkan siswa dalam proses kegiatan belajar mengajar, sehingga belajar siswa menjadi lebih bermakna karena siswa diharapkan mampu mengkaitkan materi pelajaran baru dengan struktur kognitif yang sudah ada.

\section{Peningkatan Aktivitas Siswa dengan Discovery Learning pada Konsep Redoks dan Elektrolisis}

Nilai Aktivitas siswa menunjukkan adanya peningkatan yang signifikan dari siklus I ke siklus II. Pada siklus I presentase afektif kelas sebesar 71,43\% berkategori Cukup sedangkan pada siklus II tidak ada yang berkategori cukup.

Afektif siswa pada siklus I berkategori baik sebesar 28,57\% naik menjadi $100 \%$ berkategori baik pada siklus II. Hal tersebut dikarenakan siswa sudah mulai aktif mengikuti pembelajaran di kelas.

Peningkatan tersebut dikarenakan sikap afektif sebagian besar siswa dikelas seperti bersedia mendengarkan dan memperhatikan dengan baik ketika proses pembelajaran sedang berlangsung, memberikan tanggapan ketika diberikan perintah dan tugas oleh peneliti, menjawab pertanyaan yang diberikan oleh peneliti ataupun siswa lain, berani bertanya kepada peneliti ataupun siswa lain, mampu memberikan respon berupa tanggapan ataupun sanggahan terhadap penjelasan dari peneliti maupun dari siswa lain, menyampaikan pendapat dan dapat mempertahankan pendapat tersebut, mampu berperilaku baik dan sopan saat pembelajaran berlangsung, dan mampu dan bersedia bekerja sama dengan siswa lain yang memiliki keberagaman latar belakang, pandangan, dan keyakinan. Sikap afektif siswa tersebut merupakan indikator dari setiap aspek afektif siswa. Indikator ketercapaian aktivitas siswa.

Tercapainya hasil belajar yang optimal tersebut, tidak terlepas dari banyak aspek yang mendukung selama proses pembelajaran dalam kelas. Diantaranya yakni peran peneliti selama proses pembelajaran, kesesuaian antara tindakan yang ditempuh oleh peneliti dengan rencana tindakan yang telah dipersiapkan peneliti dalam rencana pelaksanan pembelajaran (RPP) atas persetujuan peneliti yang bersangkutan, serta sikap siswa-siswi kelas XII MIPA 1 yang bersedia bekerjasama selama proses pembelajaran dengan mengikuti pembelajaran dengan baik.

Secara umum, dapat disimpulkan 
bahwa pembelajaran materi Redoks dan Elektrokimia dengan model discovery learning telah mampu meningkatkan kompetensi siswa kelas XII MIPA 1 pada SMAN 12 Bajarmasin. Hasil penelitian Dewi (2018) juga menyebutkan bahwa model pembelajaran discovery learning dapat meningkatkan hasil belajar afektif siswa pada mata pelajaran pola barisan dan deret. Hal ini disebabkan oleh siswa dapat memperoleh pengetahuan dari pengalamannya menyelesaikan masalah bukan melalui transmisi dari guru.

Sedangkan menurut Muhibbin Syah (1995), belajar adalah tahapan perubahan seluruh tingkah laku individu yang relatif menetap sebagai hasil pengalaman dan interaktif dengan lingkungan yang melibatkan proses kognitif. Sedangkan perubahan tingkah laku yang timbul akibat proses kematangan, keadaan gila, mabuk, lelah, dan jenuh tidak dapat dipandang sebagai proses belajar.

Hal ini juga dikuatkan Slameto (2001) Hasil belajar dapat diketahui dari proses penilaian, yaitu kegiatan membandingkan hasil pengukuran (skor) sifat suatu objek dengan acuan yang relevan sedemikian rupa sehingga diperoleh suatu kualitas kuantitatif.

\section{DAFTAR PUSTAKA}

Abuddin Nata, 2009. Perspektif Islam tentang Strategi Pembelajaran. Jakarta. Kencana Prenada Media Group.

Arikunto, Suharsimi. 2008. Dasar-dasar Evaluasi Pembelajaran. Bumi Aksara. Jakarta.

Dewi, Yusfita Kumala. 2018. Peningkatan Kompetensi Mata Pelajaran Matematika dengan Materi Pola Barisan dan Deret Menggunakan Model Discovery Learning pada Siswa Kelas XI IIS 1 di MAN 1
Banjarmasin Tahun Pelajaran 2016/2017. Jurnal PTK dan Pendidikan. Vol 4 (1) : 21-27.

Hamalik, Oemar. 2002. Psikologi Belajar Mengajar, Bandung: Sinar Baru Al gensindo

Hamdani. 2011. Strategi Belajar Mengajar. Bandung : Pustaka

Ibrahim, R. Dan Nana, Syaodih S. 2003. Perencanaan Pengajaran. Jakarta: Rineka Cipta

Kusuma, Wijaya dan Dedi Dwitagama. $2011 . \quad$ Mengenal Penelitian Tindakan. Kelas. Edisi : 2. Jakarta : PT Indeks. Eprilia

Muhibbin Syah. 1995. Psikologi Pendidikan Suatu Pendekatan Baru. Bandung: Remaja Rosdakarya

Putrayasa, Ida Bagus. 2013. Landasan Penididikan. Bali: Undiksha Press

Slameto. 2001. Proses Belajar Mengajar Dalam Sistem Kredit Semester. Jakarta. Bumi Aksara

Sukmadinata, Nana Syaodih. 2003. Landasan Psikologi Proses Pendidikan. Bandung: Remaja Rosdakarya

Trianto, 2010. Model Pembelajaran Terpadu. Jakarta: Bumi Aksara.

Wina, Sanjaya. 2009. Penelitian Tindakan Kelas. Jakarta : Kencana 